\title{
New nomenclatural combinations for taxa of Pentanema (Asteraceae) occurring in Ukraine
}

\author{
Ganna V. BOIKO, Olga M. KORNIYENKO, Sergei L. MOSYAKIN \\ M.G. Kholodny Institute of Botany, National Academy of Sciences of Ukraine \\ 2 Tereschenkivska Str., Kyiv 01004, Ukraine \\ bav22@ukr.net
}

Boiko G.V., Korniyenko O.M., Mosyakin S.L. New nomenclatural combinations for taxa of Pentanema (Asteraceae) occurring in Ukraine. Ukr. Bot. J., 2018, 75(5): 436-440.

Abstract. Recent molecular phylogenetic results demonstrated that the genus Inula in its traditional circumscription is polyphyletic and its type, I. helenium, belongs to a clade phylogenetically distant from the clade containing the majority of species earlier placed in Inula. The nomenclatural proposal to conserve the generic name Inula with I. hirta as the conserved type has not been adopted. Because of that the genus Inula s. str. now comprises ca. 5 species (I. helenium and its relatives). The genus Pentanema was considerably re-circumscribed to include most of taxa earlier treated in Inula. Several taxa of Inula s.l. occurring in Ukraine, however, did not have respective names available in Pentanema, but such names are needed for the forthcoming checklist of vascular plants of Ukraine (in preparation). The following new nomenclatural combinations are validated: Pentanema asperum (Poir.) G.V.Boiko \& Korniyenko, comb. nov. (Inula aspera Poir.), P. caspicum (F.K.Blum) G.V.Boiko, Korniyenko \& Mosyakin, comb. nov. (I. caspica F.K.Blum in Ledeb.), P. × medium (M.Bieb.) G.V.Boiko \& Korniyenko, comb. nov. (I. media M.Bieb.), and P. sabuletorum (Czern. ex Lavrenko) G.V.Boiko \& Korniyenko, comb. nov. (I. sabuletorum Czern. ex Lavrenko). Additionally, two new subspecies-rank combinations, P. salicinum (L.) D. Gut.Larr. et al. subsp. asperum (Poir.) Mosyakin and P. salicinum subsp. sabuletorum (Czern. ex Lavrenko) Mosyakin, comb. nov., are proposed by the third author.

Keywords: Asteraceae, Inula, nomenclature, taxonomy, Ukraine, Europe

\section{Introduction}

Recent taxonomic and molecular phylogenetic results (see Anderberg, 1991; Anderberg et al., 2005; Anderberg, Eldenäs, 2007; Nylinder, Anderberg, 2015; GutiérrezLarruscain et al., 2018, and references therein) demonstrated that the genus Inula L. (Linnaeus, 1753) (Asteraceae) in its traditionally accepted circumscription is polyphyletic. The type of the genus, I. helenium L. (designated by Britton and Brown, 1913: 457; and confirmed by Hitchcock and Green, 1929: 182; see also Art. 10.6 and 10.7 of the ICN: Turland et al., 2018), belongs to a phylo-genetically distinct clade that is rather distant from the largest clade containing most of the species earlier placed in Inula. The recognition of that clade as a separate genus required numerous new combinations and was considered disruptive for nomenclature. Because of that, the nomenclatural proposal to conserve the generic name Inula with I. hirta L. as the conserved type has been made (Santos-Vicente et al., 2012). In our opinion, that nomenclatutal solution was best for the nomenclatural stability. Unfortunately, that conservation proposal has not been adopted (Applequist, 2013) "considering that transferring the well-known medicinal species I. helenium to the unfamiliar genus Corvisartia would (C) G.V. BOIKO, O.M. KORNIYENKO, S.L. MOSYAKIN, 2018 cause confusion, particularly among non-specialists" (see Gutiérrez-Larruscain et al., 2018: 150). Thus, now the genus Inula s. str. comprises only ca. 5 species (I. helenium and its relatives).

The earliest valid generic name applicable to the clade containing most of taxa earlier placed in Inula sensu lato seems to be Pentanema Cass.; that name was originally coined by Cassini for just one species, $P$. divaricatum Cass. (published as "divaricata", but see Art. 62.2(c) of the ICN: Turland et al., 2018; $=$ Inula divaricata (Cass.) Boiss. 1875, nom illeg., non Nutt. 1818; = Vicoa divaricata (Cass.) Oliv. \& Hiern), which is morphologically rather deviant from other species placed in Inula s. 1. Later the application and circumscription of Pentanema were modified to cover ca. 15 (up to 18) species of Inuleae occurring mainly in Central, Southern, and Southeastern Asia, with extensions to Africa (see Gorshkova, 1959; Anderberg, Eldenäs, 2007; Chen, Anderberg, 2011, etc.).

Recently the genus Pentanema was considerably recircumscribed to include most of taxa usually treated in Inula in the past, and numerous required nomenclatural novelties (new combinations) have been validated by Gutiérrez-Larruscain et al. (2018).

Several taxa of Inula s.l. occurring in Ukraine, however, still do not have available names in Pentanema, 
but such names are needed for the forthcoming checklist of vascular plants of Ukraine (Mosyakin et al., in preparation). The following additional taxa not treated in Gutiérrez-Larruscain et al. (2018) were usually recognized in Eastern Europe in general and in Ukraine in particular: Inula aspera Poir. (= I. salicina L. subsp. aspera (Poir.) Hayek), I. caspica F.K.Blum in Ledeb., I. × media M.Bieb. (accepted as a hybrid I. germanica L. $\times$ I. salicina L., see Gorshkova, 1959: 452; Gubanov, 1994: 86, etc.), and I. sabuletorum Czern. ex Lavrenko (= I. salicina L. subsp. sabuletorum (Czern. ex Lavrenko) Soják) (Gorshkova, 1959; Stankov, Taliev, 1957; Dobrochaeva, 1962; Gubanov, 1994, Czerepanov, 1995, Greuter, 2006-onward, etc.). All these species-rank names are also currently accepted in the Plants of the World Online database (http://www. plantsoftheworldonline.org, accessed 27.10.2018).

New nomenclatural combinations in Pentanema for these taxa are provided below.

\section{Validation of new combinations}

Pentanema asperum (Poir.) G.V.Boiko \& Korniyenko, comb. nov.

Basionym: Inula aspera Poir. in Lam., Encycl. [J. Lamarck \& al.] Suppl. 3: 154. 1813. $\equiv$ I. salicina L. subsp. aspera (Poir.) Hayek, Prodr. Fl. Penins. Balcan. 2: 602. 1931.

Pentanema caspicum (F.K.Blum) G.V.Boiko, Korniyenko \& Mosyakin, comb. nov.

Basionym: Inula caspica F.K.Blum in Ledeb., Ind. Sem. Hort. Dorpat.: 10. 1822.

Note: In the protologue Ledebour (1822) explicitly ascribed the new species to "Blum", but later its authorship was variously cited as "Blum" (e.g., Schmalhausen, 1897: 52; Stankov, Taliev, 1957: 376; Gubanov, 1994: 86), "Ledeb." (IPNI: www.ipni. org, accessed 27.10.2018), "Blum in Ledeb." (e.g., Gorshkova, 1959: 460), "Blum ex Ledeb." (Lut, 2018onward, and several other sources), or "Blume" (e.g., Krasheninnikov, 1936: 325). No authors with the last name Blum and life dates corresponding to the period of scientific activity of Ledebour are currently listed in IPNI (1.c.). However, it is evident that Ledebour ascribed the authorship of the species name and description to Friedrich K. Blum (also known in Russia as Fedor Kondratievich Blum; ca. 1785-1820 or 1821, exact life dates unknown), a German-born medical doctor and amateur naturalist, who first visited the Lower Volga area in 1810 or 1811 and later, after his study at Dorpat University (now the University of Tartu, Estonia) in 1813-1815, since 1817 worked as a public health inspector in Astrakhan and collected plants along the Volga from Astrakhan upstream to Sarepta (now part of Volgograd). Blum evidently met Ledebour at Dorpat University where Ledebour was a professor during 1811-1836. Herbarium specimens collected by Blum were used by Ledebour when he prepared his Flora Rossica; they are still present in the Ledebour herbarium in LE, and also in MW (Lipschitz, 1947; Shcherbakova, 1979).

Pentanema $\times$ medium (M.Bieb.) G.V.Boiko \& Korniyenko, comb. nov.

Basionym: Inula media M.Bieb. 1819, Fl. Taur. Cauc. 3(Suppl.): 576., in adnot.

Note: This taxon is considered to be a hybrid between Inula germanica and I. salicina (see Gorshkova, 1959: 452; Nyárády, 1964; Gubanov, 1994: 86), now accepted as Pentanema germanicum (L.) D.Gut.Larr., SantosVicente, Anderb., E.Rico \& M.M.Mart.Ort. and P. salicinum (L.) D.Gut.Larr., Santos-Vicente, Anderb., E.Rico \& M.M.Mart.Ort. (see Gutiérrez-Larruscain et al., 2018: 159).

Pentanema sabuletorum (Czern. ex Lavrenko) G.V.Boiko \& Korniyenko, comb. nov.

Basionym: Inula sabuletorum Czern. ex Lavrenko, Ind. Sem. Hort. Bot. Charjkov. 1925: 7. 1926. $\equiv$ I. salicina L. subsp. sabuletorum (Czern. ex Lavrenko) Soják, Čas. Nár. Mus., Odd. Př́r.r., 140(3-4): 131. 1972.

Note: The original text from the protologue by Lavrenko was reproduced in toto in Botschantzev (1959: 636).

The two species recognized above as Pentanema asperum and $P$. sabuletorum are closely related to $P$. salicinum; they were sometimes treated as subspecies of the latter (see Soó, 1972; Gubanov, 1994, Antipova, 1997, etc.). However, most of Russian and Ukrainian authors (e.g., Stankov, Taliev, 1957; Gorshkova, 1959; Dobrochaeva, 1962; Czerepanov, 1985; Mosyakin \& Fedoronchuk, 1999, and references therein), who usually applied a rather narrow species concept, accepted these taxa as separate species of Inula. The names I. aspera and I. sabuletorum (as well as I. caspia and I. media) are currently listed as accepted names in the Plants of the World Online (http://www. plantsoftheworldonline.org/, accessed 27.10.2018) and some other databases. This option is also accepted here by two authors of the present article (Ganna Boiko 
and Olga Korniyenko), who prefer the species rank for $P$. asperum and $P$. sabuletorum.

However, the wide morphological variation within the $P$. salicinum group and the presence of forms supposedly transitional or morphologically intermediate between $P$. salicinum s. str., P. asperum, and $P$. sabuletorum resulted in recognition of several infraspecific entities within the taxon earlier known as Inula salicina s.l. (see above). Because of that the third author (Sergei Mosyakin) is in favor of the subspecies rank for the two taxa originally described as Inula aspera and $I$. sabuletorum, to be treated now as two subspecies of $P$. salicinum.

The corresponding subspecies-rank combinations are validated below. They should not be treated as alternative names (which are invalid under the current Code: Art. 36.3 of the ICN: Turland et al., 2018; see also Mosyakin, McNeill, 2016) because, even if validated in the same publications, they are proposed and accepted by different authors. Alternative names are defined by the ICN (Art. 36.3 and Glossary: Turland et al., 2018) as names based on the same type and "accepted simultaneously for the same taxon by the same author [emphasis added] and accepted as alternatives by that author [emphasis added] in the same publication".

Thus, the species-rank combinations are validated above by Boiko and Korniyenko, while the subspeciesrank combinations below are explicitly accepted by Mosyakin.

Pentanema salicinum (L.) D.Gut.Larr. et al. subsp. asperum (Poir.) Mosyakin, comb. nov.

Basionym: Inula aspera Poir. in Lam., Encycl. [J. Lamarck \& al.] Suppl. 3: 154. 1813. $\equiv$ I. salicina L. subsp. aspera (Poir.) Hayek, Prodr. Fl. Penins. Balcan. 2: 602.1931.

Pentanema salicinum (L.) D.Gut.Larr. et al. subsp. sabuletorum (Czern. ex Lavrenko) Mosyakin, comb. nov.

Basionym: Inula sabuletorum Czern. ex Lavrenko, Ind. Sem. Hort. Bot. Charjkov. 1925: 7. 1926. $\equiv$ I. salicina L. subsp. sabuletorum (Czern. ex Lavrenko) Soják, Čas. Nár. Mus., Odd. Př́r. , 140(3-4): 131. 1972.

Another subspecies, Inula salicina subsp. denticulata (Borbás) Soó, was sometimes recognized as a presumably endemic Pannonian psammophytic taxon (see Soó, 1972). Nomenclature and identity of that taxon remain problematic. The species name I. denticulata was briefly mentioned by Borbás (1888:
325) with the reference to "I. Pseudosalicina Simk. non Schur", which can be viewed as indirect reference to I. pseudosalicina Simonk. (Simkovics, 1878: 151, with a brief Hungarian description), but not to the taxon described by Schur as I. hybrida Baumg. var. [a.] pseudosalicina Schur (as "Pseudo-salicina": Schur, 1866: 312). The name I. pseudosalicina attributed to "Simkov. ex Beck" is currently listed in IPNI (www. ipni.orh, accessed 27.10.2018), but that name was mentioned by Beck (1882: 303) only in synonymy of I. salicina. In the Plants of the World Online (http:// www.plantsoftheworldonline.org/taxon/urn:lsid:ipni. org:names:225839-1, accessed 27.10.2018) the name I. denticulata Borbás is listed as a synonym of the later but anyway accepted (!) name I. sabuletorum. In fact, possible identity of the mentioned taxa with the East European taxon known as I. sabuletorum is at least very questionable.

Because of the remaining taxonomic and nomenclatural uncertainties regarding the proper application and typification (and in some cases even validity) of various names used for the Pannonian and some other central-southeastern European (mainly Hungarian and Romanian) plants of the Pentanema salicinum / Inula salicina group (e.g., in Schur, 1972; Borbás, 1888; Beck, 1882, Nyárády, 1964, etc.), we prefer here to use for the psammophytic race occurring in Ukraine the epithet sabuletorum that is certainly applicable to our taxon.

\section{Acknowledgments}

This research was in part supported by the National Academy of Sciences of Ukraine (project 0117U004024).

\section{REFERENCES}

Anderberg A.A. Taxonomy and phylogeny of the tribe Inuleae (Asteraceae). Pl. Syst. Evol., 1991, 176: 75-123. https://doi.org/10.1007/BF00937947

Anderberg A.A., Eldenäs P. Tribe Inuleae. In: The families and genera of vascular plants. Vol. 8, Flowering Plants: Eudicots; Asterales. Eds J.W. Kadereit, C. Jeffrey. Berlin: Springer, 2007, pp. 374-391.

Anderberg A.A., Eldenäs P., Bayer R.J., Englund M. Evolutionary relationships in the Asteraceae tribe Inuleae (incl. Plucheeae) evidenced by DNA sequences of $n d h \mathrm{~F}$; with notes on the systematic positions of some aberrant genera. Organisms, Diversity \& Evolution, 2005, 5: 135-146. https://doi:10.1016/j.ode.2004.10.015

Antipova E.M. Inula. In: Flora Sibiriae. Ed. I.M. Krasnoborov. Novosibirsk: Nauka, 1997, vol. 13, pp. 51-56. [Антипова Е.М. Inula. В кн.: Флора Сибири. Ред. И.М. Красноборов. Новосибирск: Наука, 1997, т. 13, c. $51-56$. 
Applequist W.L. Report of the Nomenclature Committee for Vascular Plants: 65. Taxon, 2013, 62: 1315-1326. https:// doi.org/10.12705/626.49

Beck G. Inulae Europae. Die Europäischen Inula-arten. Denkschriften der Kaiserlichen Akademie der Wissenschaften (Wien). Mathematisch-Naturwissenschaftliche Classe, 1882, 44(2): 283-339.

Borbás A. [Correspondence section, untitled letter]. Oesterreichische Botanische Zeitschrift, 1888, 38: 324-325.

Botschantzev V. [Bochantsev V.P.]. Repertorium diagnosum plantarum novarum in editionibus rossicis minus cognitis antea descriptarum, II. Notulae Systematicae ex Herbario Instituti Botanici nomine V.L. Komarovii Academiae Scientiarum URSS [Ботанические материаль Гербария Ботанического института им. В.Л. Комарова АН CCCP], 1959, 19: 622-649.

Britton N.L., Brown A. An illustrated flora of the northern United States, Canada and the British possessions, from Newfoundland to the parallel of the southern boundary of Virginia, and from the Atlantic Ocean westward to the 102d meridian. Ed. 2. New York: Charles Scribner's Sons, 1913, vol. 3, 637 pp.

Cassini H. Aperçu des Genres nouveaux formés par M. Henri Cassini dans la famille des Synanthérées. Huitième fascicule (1) [Issue 8(1)]. Bulletin des Sciences, par la Société Philomatique de Paris, 2018, [vol. of 1818]: 73-77.

Chen Y.S., Anderberg A.A. Tribe Inuleae. In: Flora of China. Eds Z.Y. Wu, P.H. Raven, D.Y. Hong. Beijing: Science Press \& St. Louis: Missouri Botanical Garden Press, 2011, vol. 20-21 (Asteraceae), pp. 820-850.

Czerepanov S.K. Vascular plants of Russia and adjacent states (the former USSR). Cambridge; New York: Cambridge University Press, 1995, $\mathrm{x}+516 \mathrm{pp}$.

Dobrochaeva [Dobroczajeva] D.M. Inula. In: Flora of the Ukrainian SSR. Ed. O.D. Visyulina. Kyiv: Academy of Sciences of the Ukrainian SSR Publ., 1962, vol. 11, pp. 110-135. [Доброчаєва Д.М. Inula. В кн.: Флора УРСР. Київ: Вид-во АН УРСР, 1962, т. 11, с. 110-135.].

Greuter W. (2006-onward): Compositae (pro parte majore). In: Greuter W. \& von Raab-Straube E. (ed.): Compositae. Euro +Med Plantbase - the information resource for EuroMediterranean plant diversity. Available at: http://ww2. bgbm.org/euroPlusMed/PTaxonDetail.asp? NameId=14 $103 \&$ PTRefFk $=7000000$

Gutiérrez-Larruscain D., Santos-Vicente M., Anderberg A.A., Rico E., Martínez-Ortega M.M. Phylogeny of the Inula group (Asteraceae: Inuleae): Evidence from nuclear and plastid genomes and a recircumscription of Pentanema. Taxon, 2018, 67(1): 149-164.

Gorshkova S.G. Inula. In: Flora of the USSR. Vol. 25. Ed. B.K. Schischkin. Moscow \& Leningrad: Academy of Sciences of the USSR Publ., 1959, pp. 433-473. [Горшкова С.Г. Inula. В кн.: Флора СССР. Ред. Б.К. Шишкин. М.; Л.: Изд-во АН СССР, 1959, т. 25, с. 433-473.]

Gubanov I.A. Inula. In: Flora Partis Europaeae URSS. Ed. N.N. Tzvelev. Leningrad: Nauka, 1994, vol. 7, pp. 80-87. [Губанов И.А. Inula. В кн.: Флора европейской части
СССР. Ред. Н.Н. Цвелев. Ленинград: Наука, 1994, т. 7, c. 80-87].

Hitchcock A.S., Green M.L. Proposal by A.S. Hitchcock (Washington) and M.L. Green (Kew) [on Linnean generic names]. In: International Botanical Congress, Cambridge (England), 1930. Nomenclature. Proposals by British Botanists. London: Printed under the authority of His Majesty's Stationery Office, by Wyman \& Sons, Ltd., 1929, pp. 110-195.

Krasheninnikov I.M. Tribe Inuleae. In: Flora Austro-Orientis Partis Europensis URSS, Fasc. 6. Ed. B.K. Schischkin. Moscow \& Leningrad: Typis et impensis Academiae Scientiarum URSS, 1936, pp. 319-329. [Крашенинников И.М. Триба Inuleae. В кн.: Флора Юго-Востока Европейской части СССР. Ред. Б.К. Шишкин. Вып. 6. М.; Л.: Изд-во АН СССР, 1936, с. 319-329.].

Ledebour C.F. Index Seminum Horti Academici Dorpatensis, 1822. Dorpati Livonorum [Tartu], 1822, 20 pp.

Linnaeus C. Species Plantarum. Holmiae [Stockholm], Laurentius Salvius, 1753, vols 1-2, 1200 pp. https://doi. org/10.5962/bhl.title.37656

Lipschitz S. [Lipshits S.Yu.]. Botanicorum Rossicorum Lexicon Biographo-Bibliographicum. Mosquae [Moscow]: Editio Societatis Naturae Curiosorum Mosquensi [MOIP Publ.], 1947, vol. 1, xii + 335 pp. [Липшиц С.Ю. Русские ботаники. Биографо-библиографический словарь. М.: Изд-во МОИП, 1947. Т. 1. хіi + 335 с.].

Lut C. (in cooperation with J.F. Veldkamp). Seed Lists: Guide to the plant species descriptions published in seed lists from Botanic Gardens for the period 1800-1900. Leiden: Naturalis Biodiversity Center, 2018-onward. Available at: http://seedlists.naturalis.nl/content/seedlists (accessed 27.10.2018).

Mosyakin S.L., Fedoronchuk M.M. Vascular plants of Ukraine. A nomenclatural checklist. Kiev, 1999, xxiii + 345 pp. http://dx.doi.org/10.13140/2.1.2985.0409

Mosyakin S.L., McNeill J. (327-328) Proposals to clarify certain aspects of the rules on alternative names. Taxon, 2016, 65(4):907-908.http://dx.doi.org/10.12705/654.38

Nyárády E.I. Inula. In: Flora Republicii Populare Romîne, vol. 9. Bucureşti: Editura Academiei Republicii Populare Romîne, 1964, pp. 264-291.

Nylinder S., Anderberg A.A. Phylogeny of the Inuleae (Asteraceae) with special emphasis on the InuleaePlucheinae. Taxon, 2015, 64: 110-130. https://doi. org/10.12705/641.22

Santos-Vicente M., Martínez-Ortega M.M., Rico E. (2111) Proposal to conserve the name Inula (Asteraceae) with a conserved type. Taxon, 2012, 61: 1331-1332.

Schmalhausen I.F. Flora of Middle and Southern Russia, Crimea and the North Caucasus. Kiev: I.N. Kushnerev \& Co., 1897, vol. 2, xvi + 752 pр. [Шмальгаузен И.И. Флора Средней и Южной России, Крыма и Северного Кавказа. Киев: И.Н. Кушнерев и К., 1897, т. 2, хvi + 752 с.]

Schur P.J.F. Enumeratio plantarum Transsilvaniae. Vindobonae [Vienna]: apud Guilielmum Braumüller, 
1866. xviii + 984 pp. https://doi.org/10.5962/bhl. title.9958

Shcherbakova A.A. History of botany in Russia until the 1860 s (pre-Darwinian period). Novosibirsk: Nauka (Siberian Branch), 1979, 365 pp. [Шербакова А.А. История ботаники в России до 60-х годов ХІХ века (додарвиновский период). Новосибирск: Наука (Сибирское отделение), 1979, 365 с.].

Simkovics [Simonkai] L. Néhány Közep-Magyarországi növényröl. Természetrajzi Füzetek [Naturhistorische Hefte], 1878, 2: 148-153.

Soó R. Systematisch-nomenklatorische Bemerkungen zur Flora Mitteleuropas mit Beziehungen zur sudosteuropäischen Flora. Feddes Repertorium, 1972, 83(3): 129-212.

Stankov S.S., Taliev V.I. Identification manual of higher plants of the European part of the USSR. Moscow: Sovetskaya Nauka, 1957, 742 pp. [Станков C.С., Талиев В.И. Определитель высших растений Европейской части СССР. Изд. 2. М.: Советская наука, 1957, 742 с.].

Turland N.J., Wiersema J.H., Barrie F.R., Greuter W., Hawksworth D.L., Herendeen P.S., Knapp S., Kusber W.-H., Li D.-Z., Marhold K., May T.W., McNeill J., Monro A.M., Prado J., Price M.J., and Smith G.F. (eds.). International Code of Nomenclature for Algae, Fungi, and Plants (Shenzhen Code) adopted by the Nineteenth International Botanical Congress, Shenzhen, China, July 2017. Regnum Vegetabile, 2018, 159: i-xxxviii + 1-254. https://doi.org/10.12705/Code.2018

Recommended for publication by Submitted 11.10.2018 M.M. Fedoronchuk

Бойко Г.В., Корнієнко О.М., Мосякін С.Л. Нові номенклатурні комбінації для таксонів роду Pentanema (Asteraceae) флори України. Укр. бот. журн., 2018, 75(5): 436-440.

Результати недавніх молекулярно-філогенетичних досліджень показали, що род Inula у традиційному розумінні є поліфілетичним, а його тип, I. helenium, належить до клади, що філогенетично віддалена від клади, що містить більшість видів, які раніше включалися до Inula. Номенклатурна пропозиція законсервувати родову назву Inula із законсервованим типом I. hirta не була прийнята. Через це род Inula тепер включає приблизно 5 видів (I. helenium та споріднені види). Обсяг роду Pentanema був значно змінений, завдяки чому до нього зараз включено більшість таксонів, що раніше розглядалися у складі Inula. Проте, декілька таксонів Inula s. 1., які поширені в Україні, не мали відповідних назв у роді Pentanema, але такі назви є необхідними для запланованого нового видання номенклатурного конспекту судинних рослин України. Здійснені такі нові номенклатурні комбінації: Pentanema asperum (Poir.) G.V.Boiko \& Korniyenko, comb. nov. (Inula aspera Poir.), P. caspicum (F.K.Blum) G.V.Boiko, Korniyenko \& Mosyakin, comb. nov. (I. caspica F.K.Blum in Ledeb.), $P . \times$ medium (M.Bieb.) G.V.Boiko \& Korniyenko, comb. nov. (I. media M.Bieb.), P. sabuletorum (Czern. ex Lavrenko) G.V.Boiko \& Korniyenko, comb. nov. (I. sabuletorum
Czern. ex Lavrenko). Крім того, дві нові комбінації у ранзі підвиду запропоновані одним з авторів: P. salicinum (L.) D. Gut.Larr. et al. subsp. asperum (Poir.) Mosyakin, comb. nov. та $P$. salicinum subsp. sabuletorum (Czern. ex Lavrenko) Mosyakin, comb. nov.

Ключові слова: Asteraceae, Inula, номенклатура, систематика, Україна, Европа.

Бойко А.В., Корниенко О.М., Мосякин С.Л. Новые номенклатурные комбинации для таксонов рода Pentanema (Asteraceae) флоры Украины. Укр. бот. журн., 2018, 75(5): 436-440.

Результаты недавних молекулярно-филогенетических исследований показали, что род Inula в традиционном понимании является полифилетическим, а его тип, I. helenium, относится к кладе, филогенетически удаленной от клады, включающей большинство видов, ранее относимых к Inula. Номенклатурное предложение законсервировать родовое название Inula с законсервированным типом I. hirta не было принято. Поэтому род Inula теперь включает лишь около 5 видов (I. helenium и родственные виды). Объем рода Pentanema был значительно пересмотрен, вследствие чего в этот род сейчас включено большинство таксонов, ранее рассматриваемых в составе Inula. Однако несколько распространенных в Украине таксонов Inula s.l. не имели соответствующих названий в роде Pentanema, но такие названия необходимы для планируемого нового издания номенклатурного конспекта сосудистых растений Украины. Осуществлены следующие новые номенклатурные комбинации: Pentanema asperum (Poir.) G.V.Boiko \& Korniyenko, comb. nov. (Inula aspera Poir.), P. caspicum (F.K.Blum) G.V.Boiko, Korniyenko \& Mosyakin, comb. nov. (I. caspica F.K.Blum in Ledeb.), $P . \times$ medium (M.Bieb.) G.V.Boiko \& Korniyenko, comb. nov. (I. media M.Bieb.), P. sabuletorum (Czern. ex Lavrenko) G.V.Boiko \& Korniyenko, comb. nov. (I. sabuletorum Czern. ex Lavrenko). Кроме того, одним из авторов предложены две новые комбинации в ранге подвида: P. salicinum (L.) D.Gut.Larr. et al. subsp. asperum (Poir.) Mosyakin, comb. nov. и $P$. salicinum subsp. sabuletorum (Czern. ex Lavrenko) Mosyakin, comb. nov.

Ключевые слова: Asteraceae, Inula, номенклатура, систематика, Украина, Европа. 